\title{
Comparative Empirical Analysis of
} Financial Failures of Enterprises with Altman Z-Score and VIKOR Methods: BIST Food Sector Application

\author{
Mehmet Apan ${ }^{1}$, Ahmet Öztel $^{2}$ and Mehmet İslamoğlu ${ }^{3}$
}

\begin{abstract}
This study includes an empirical review of the financial failure of enterprises. For the empirical analysis, 2008-2014 period data for enterprises operating in the Food and Drink Sector traded on BIST (Borsa Istanbul), were used. The financial failures of these enterprises were first determined according to the Altman Z-Score method, and the financial success rankings of the enterprises were then determined by the VIKOR (VIseKriterijumsa Optimizacija I Kompromisno Resenje) method, which is one of the MCDM (Multiple Criteria Decision-Making) methods. The empirical analysis results obtained from these two different methods have been comparatively evaluated and interpreted.

In this study, the VIKOR method is suggested as an alternative method for financial failure analysis.
\end{abstract}

JEL Classification: G33, C44, C39.

Keywords: Altman Z-Score, VIKOR, Financial Failure, Borsa Istanbul-Food, Beverage Index (BIST XGIDA).

Acknowledgement: This study is an extension of an oral presentation given at the 17th EBES Conference in Venice, Italy, October 2015.

\footnotetext{
${ }^{1}$ University of Karabuk, Turkey

${ }^{2}$ University of Bartın, Turkey

${ }^{3}$ University of Karabuk, Turkey
} 


\section{Introduction}

There are many different methods besides the Altman Z-Score in determining the financial failure of enterprises. In this context, ANNs (Artificial Neural Networks) (Kılıç \& Seyrek, 2012; Akkaya et al., 2009; Akay \& Gökdemir, 2015), Logit Models (Akay \& Gökdemir, 2015), GRA (Grey Relational Analysis) and Logistic Regression Analysis (Baş \& Çakmak, 2012), Data Mining and Logistic Regression Analysis (Kaygin et al., 2016), Factor Analysis and Discriminant Analysis (Cengiz et al., 2015; Selimoglu \& Orhan, 2015), are used by researchers to determine financial failure. The literature from outside the finance sector was taken into account in the study.

The study focuses on the measurement and comparison of the financial activities of selected food and drink enterprises traded on BIST. In the second chapter after the introduction, the literature on the subject is included in the search. In the third chapter, the Altman Z-Score and VIKOR are explained. In the fourth section, the financial performance analysis results of the firms are given comparatively by years. In the fifth section, the conclusions and suggestions reached are discussed.

\section{Literature review}

\section{Literature Review of Altman Z-Score}

Many studies from different sectors are included in the literature in order to determine the financial failures of the enterprises. In this context, the financial performance or financial success / failure of the enterprises are determined with the help of financial ratios (Bağc1, 2015).

The efforts to determine the financial failures of businesses first began with corporate bankruptcies, which took place with the Great Depression of 1929. In this framework, the first study on the financial failure prediction of businesses is the discriminant analysis developed by R.A. Fisher (1936). One of the most important contributions to the development of models for financial failure prediction is the work done by Beaver (1966). In this study, 5-year periods of enterprises were examined. The profitability ratios, the liquidity ratios, and the ratios showing debt repayment power were the basic variables used by Beaver in predicting financial failure (Beaver, 1966).

Z-Score (Altman, 1968), developed by Altman, is one of the most widely accepted methods of determining financial failure. This method has become widespread due to its reliance on accounting data and ease of implementation. The high success rate of the method is another reason for the frequency of its use (Kulal1, 2016).

The Z-Score method is used in academic literature applications and is also used by institutions and organizations in the real sector to achieve different goals. Market surveillance, early warning, corporate risk measurement, and rating procedures are some examples. On the other hand, there are different business financial failure prediction models developed by Altman (Özdemir, 2014). There are many studies that have tried to determine financial failure with the Altman Z-Score method. Some of these studies are summarized below:

A new model has been developed by Almamy et al. (2016), adding the cash flow variable to the Altman Z-Score method. Using this model, the financial success of the enterprises was 
determined during the financial crisis in England. In the study, the data for the years 2000-2013 were used. As a result of the study, it was determined that the predictive power of the new model (J-UK) was $82.9 \%$ which shows the correctly classification of the non failed companies involved in the analysis.

Ko et al. (2016) used the Altman Z-Score method to determine the financial performances of solar energy companies in Taiwan. For empirical analysis, 2009-2014 period data from the energy sector was used, drawn from the Taiwan Economic Journal database. The findings show that companies experiencing financial difficulties experience a decline in profitability.

In the research study implemented by Kulalı (2016), the Altman Z-Score model was applied to the financial data of 19 companies that went bankrupt when trading in the BIST between 20002013. By applying Altman Z-Score model in order to predict financial failure of the companies involved in the analysis, the financial failure was estimated by $95 \%$ one year $90 \%$ two years earlier which shows the success of the Altman Z-Score model in predicting financial failure.

In the study conducted by Rybárová et al. (2016), the financial failures of the enterprises were determined using a 2013 dataset of 109 operators in the Slovak Republic construction sector. The analysed operators were only the businesses with a turnover over 10 million EUR. For the analysis were used three variants of Altman Z-Score - Altman Z-Score by Neumaier (Z1), Altman Z-Score for non-productive and start-ups businesses (Z2) and Altman Z-Score for other businesses (Z3). Evaluation of the financial stability of the company by selected models of Altman Z-Score is compared with the business's rating by solvency index, which develops the business Creditreform, s.r.o. to verify the results of bankruptcy models. Solvency index was grouped into the three zones based on the final results in order to ensure comparability with the empirical results obtained according to Altman Z-Score. In the study, when the results of solvency index were compared with the results of Altman Z-Score, the results would be almost same by the third variant of Altman Z-Score - Altman Z-Score for other businesses. Consequently, for the results' verifying of the analysis through Altman Z-Score for other businesses are recommended to carry out further analysis of the construction industry.

Toraman and Karaca (2016) proposed a new model based on the Altman-Z-Score for the financial failure analysis of the firms with a financial dataset of 17 firms (2010-2013) in the BIST Chemical sector. Altman Z-Score Model classifies firms into three zones with respect to their calculated $\mathrm{Z}$-Scores. When $\mathrm{Z}<1.81$ refers to high risk (distress zone), $1.81<\mathrm{Z}<3$ displays shows neutrality (grey zone) and $Z>3$ means there is no risk of financial failure (safe zone). According to aforementioned information, it is assumed that $Z<3$ criterion is in the financial risk zone based on the experience of researchers and the dependent variable is determined accordingly to perform Binary Logistic Regression Analysis (BLRA). In the study, BLRA is used because the dependent variable is categorical with two options (successful / unsuccessful). The independent variables which may have impact on Z-Score were selected among Liquidity, Turnover, Leverage and Profitibility Ratios which are normally distributed. The logistic regression analysis has shown that net working capital in total assets, share of stocks, and total debts all have a significant effect on the financial performances of the enterprises.

Bağc1 (2015) conducted a study to analyze the financial situation of the firms in textile and apparel industry and to understand the situation of the industry in the face of a possible economic crisis. By using the financial data of 24 companies operating in the textile and apparel industry traded on BIST between 2008-2013, the financial situation of firms was examined by performing 
ratio analysis technique. And for the same period by employing Altman Z-Score model developed by Edward Altman (1966), Z-scores were calculated by using the financial ratios of the textile industry consisting the entire textile industry firms traded on BIST. According to the empirical results, revealing Z-Scores between 2008-2013 were 0.63, 0.57, 0.60, 0.62, 0.63, 0.67 respectively which shows that the industry is exposed to high risk in terms of financial failure.

Yilmaz and Yildiran (2015) wanted to test the estimated capacity of the Altman Z-Score method with financial data covering the years 2001-2006 for 18 bankrupt firms and 18 successful firms listed in BIST. Using the financial ratios of companies and their Altman Z-Score values, it is estimated how close each business is to bankruptcy. Then, these estimates were compared with actual data from BIST. In these comparisons, it was found that the Altman Z-Score estimated 16 out of 18 successful firms and 10 out of 14 unsuccessful firms. Discriminant Analysis was conducted to understand which of the financial ratios used in the Altman Model better distinguishes financial success and failure. Except for Retail Earnings / Total Assets, the remaining four ratios in Altman Model are useful in differentiating successful and bankrupt businesses. It is also determined by empirical analysis that discriminant analysis correctly predicts successful and unsuccessful businesses at a rate of $94 \%$.

A study conducted by Bozkurt (2014) aimed to determine the models that best explain the systematic change of risk for bankruptcy probabilities of firms traded on BIST. A total of 127,008 observations were used from the quarterly periods between March 2005 and December 2011 of 168 firms that were traded on BIST. This dataset used standardized normal distribution values of eight different model scores to determine firm bankruptcy risks. The study found that the probability of high bankruptcy increases the systematic risk, and that Altman-Z, Ohlson-O, and Springate-S bankruptcy models are all effective models for BIST.

Civan and Day1 (2014) aimed to measure the financial failures of the enterprises with the data for 2008-2012 of the health enterprises affiliated with the Zonguldak Public Hospitals Union. Altman Z-Score and ANNs methods were applied to the dataset. According to Altman Z-Score results, it is estimated that the number of unsuccessful enterprises is $4 \%$, and that of firms with a $95 \%$ chance of failing within one year is $27 \%$. In addition, $31 \%$ of businesses were classified as unsuccessful, and $69 \%$ were classified as successful. On the other hand, the ANNs models showed a classification success of $85 \%$. Unsuccessful firms were estimated incorrectly for 2 periods, while they were correctly estimated for 27 periods. In the classification model, it is estimated that $100 \%$ of the companies are successful.

Mishu and Codreanu (2014) aimed to identify and analyze the financial success and bankruptcy situation of construction companies in Romania. Conan and Holder applied Altman methods to the dataset containing the years 2008-2012. The results obtained were analyzed comparatively.

Different Altman Z-Score models were applied by Özdemir (2014) using financial data based on the Uniform Accounting System (UAS) in Turkey. It was aimed at empirically evaluating the applicability of the Z-Score models, both to publicly traded and non-traded enterprises in Turkey. This model has been applied to 80 of the publicly traded (large enterprise) and 62 nontraded (small - or medium - scale) enterprises with a total of 142 manufacturing operations with three different Z-Score methods. It was determined in the study that the overall success of the Altman Z-Score models for both publicly traded and non-traded enterprises is low due to high error rates. Looking at the coherence of the unsuccessful groupings of Z-Score models, publiclyowned enterprises have achieved close results. On the other hand, in publicly-owned enterprises, 
it was determined that there is a level of harmony of $96.67 \%$ in terms of the classification results for the Z-Score models.

Rim and Roy (2014) identified the financial failures of the manufacturing enterprises in Lebanon by the Altman Z-Score method. The analysis data included 11 enterprises, including the years 2009-2011. In the study, the financial failures of enterprises were determined comparatively by years. Besides predicting financial failures of enterprises operating in financial and non-financial industries, the study found that the Altman Z-Score can serve as a barometer for classifying Lebanese manufacturing enterprises within the same sub-business sector.

Yildiz (2014) determined the Altman Z-Score values by using the financial dataset of 35 firms in BIST-100 Index. In addition, by incorporating the corporate governance index, a dual logistic regression method was used to determine the "investable" or "non-investable" status of the firms. In this study, it was determined that there was a meaningful relationship between companies' investable positions and Altman Z-Scores. On the other hand, it was found that there was no significant relationship between corporate governance indices and investable positions. The results of this analysis determined that the financial dataset were effective in the evaluation of the company, and that it did not adequately reflect the ratings of corporate governance.

İskenderoğlu and Karakozak (2013) examined the effect of the 2008 global crisis on the financial ratios of BIST-manufacturing enterprises. In the study, various financial ratios and Altman ZScore values of 158 manufacturing companies were calculated for the 2007-2011 period. According to the Altman Z-Score, it was determined that bankruptcy risks of the firms increased from the first quarter of 2008 to the last quarter of 2009.

In the study conducted by Zeytinoglu and Akarım (2013), discriminant analysis was applied to the 20 financial ratios that were formed by using the dataset of 115 firms that were traded on BIST between 2009-2011. Subsequently, the Altman Z-Score method was applied to determine the financial success of the businesses. In the study, capital adequacy and net working capital / asset ratios were found to be important for three periods. According to the generated models, the classification success was $88.7 \%$ for $2009,90.4 \%$ for 2010 , and $92.2 \%$ for 2011 , respectively.

Yi (2012) examined the effectiveness of the Altman Z-Score method in determining the financial failures of the 40 real estate investment companies whose shares are traded on China using the financial dataset. As a result of the study, Altman Z-score model is suitable for early warning of China's listed real estate companies to some extent, but the accuracy rate of its prediction is lower than $90 \%(86.7 \%)$, which is not very high. There are two reasons why its accuracy rate is not high enough. Firstly, due to the difference between China and US securities markets, the model established with the financial data of US companies examined by Professor Altman is not very suitable for the research of financial early warning system of China's listed companies; secondly, Z-Score early warning model established by professor Altman fits listed nonmanufacturing companies, but those listed non-manufacturing companies, which cover many different industries, have not been classified in a detailed way, so this model has very low practicality.

Terzi (2011) determined the Altman Z-Score values using the 2009-2010 financial dataset for the 22 companies listed in the BIST food sector. Six ratios were determined for the model generated by single and multiple statistical analyses. It was determined that the developed model had an accuracy rate of $90.9 \%$. In addition, with the applied discriminant analysis, it was determined 
that the return on assets ratio and debt-equity ratio had impact on determining the financial success of the companies.

Poyraz and Uçma (2006) aimed to measure the financial failure levels of the tourism, textile, agricultural products-food, and transportation and vehicles sectors in the crises of 1994 and 2001 with the Altman Z-Score model. In this study, the Central Bank of the Republic of Turkey (CBRT) sector balance sheet data was used for the 1992-2003 period. According to the Altman Z-Score model, the sectors of tourism, textile, agricultural products-food and transport, which constitute the main exporting sectors, were not affected much by the 1994 and 2001 financial crises.

Grice and Ingram (2001) proposed the generalization of the Altman Z-Score financial failure prediction model. In this study, a dataset for 972 companies for the years 1985-1987 and 902 companies for 1988-1991 were used. The study sought answers to three questions. First, is Altman's original model useful in predicting recent bankruptcies? Second, is it useful in estimating the bankruptcies of non-manufacturing firms as well as manufacturing firms? Third, is it useful for predicting bankruptcy as well as financial distress conditions? The results consistent with the Altman Z-Score model.

\section{Literature Review on VIKOR Method}

Çevik and Gökşen (2016) presented a decision support system based on the AHP (Analytical Hierarchy Process) -VIKOR integration in the evaluation of investment projects.

In the work done by Kara and Ecer (2016), the choice of best supplier is made by using AHP and VIKOR integration method in a textile firm in Uşak Province. In the study, the four main criteria for supplier selection are cost, quality, delivery, profile and flexibility, and 12 subcriteria such as unit price, transportation cost, defect rate, quality problem analysis, product quality, fulfillment of delivery time, fulfillment of delivery quantity, supplier's financial structure, image, capability and capacity of the supplier, warranty, and after-sales services have been identified. In this study, the AHP method was used to determine the relative importance of the criteria, and the VIKOR method was used to rank the alternatives. According to the analysis results, the delivery criterion has the highest weight (0.377), and the second most important criterion was quality $(0.196)$. Then, in terms of weighted value, it was determined that elasticity is 0.186 , cost is 0.135 , and profile is 0.107 .

The integrated approach of AHP and VIKOR is employed by Demircanlı and Kundakc1 (2015) to evaluate the performance of forward football players. According to the proposed approach, firstly AHP method is used to determine the weights of the criteria and then with the help of VIKOR method the ranking of alternatives are determined and a compromise solution is obtained. In the empirical analysis section, the proposed approach is used to evaluate the performance of forward football players and a ranking between these players according to the performance is obtained.

In the study conducted by Liu et al. (2015), failure and impact analysis were emphasized, but some deficiencies were emphasized. For this purpose, a new VIKOR method is proposed using Fuzzy-AHP and Entropy methods to determine the risk factors of failure. This model aimed to help with potential applications. 
Rostamzadeh et al. (2015) illustrated the case of a laptop manufacturer in Malaysia that pursues to evaluate green supply chain management (GSCM) indicators among its practitioners. They developed a quantitative evaluation model to measure the uncertainty of GSCM activities and applied an approach based on VIKOR method which is an extension of intuitionistic fuzzy environment aiming to solve the green multi-criteria decision making (GMCDM) problem. The criteria used in the model were co-design, green production, green purchasing, green recycling, green transportation, and green storage. The triangular fuzzy numbers (TFNs) were used to handle imprecise numerical quantities. Then, a hierarchical MCDM model was proposed based on fuzzy sets theory and VIKOR method to deal with the problem. The results showed the alternative ranks of the four evaluated companies which was based on their performance in GSCM initiatives.

Önder and Yıldırım (2014) proposed a model of 11 logistic hubs ranking in Turkey by using AHP and VIKOR methods simultaneously. Subjective and objective opinions of logistic managers / experts turned into quantitative form with AHP. VIKOR technique was used for calculating the logistic villages' ranks. They aimed to rank the 11 logistic villages in Turkey including İstanbul (Halkalı), Balıkesir (Gökköy), Eskişehir (Hasanbey), İzmit (Köseköy), Uşak, Denizli (Kaklık), Samsun (Gelemen), Mersin (Yenice), Kayseri (Boğazköprü), Konya (Kayacık) and Erzurum (Palandöken). According to the ranking result, Samsun (Gelemen) became the first, while Balıkesir (Gökköy) took the last place.

Rezaie et al. (2014) aimed to determine the financial performance of 27 cement companies traded on the Iranian Stock Exchange through the integrated fuzzy AHP-VIKOR model. In this study, a 2008-2009 period dataset of companies was used. As a result of the empirical analysis, the ranking of firms according to their performances was made.

Shen et al. (2014) conducted a stock selection with the VIKOR-DANP (DEMATEL-based Analytical Network Process) intercept model, except for the classic investment behavior, using the May 2009-December 2012 period dataset for the 4 most traded shares of the semiconductor sector in the Taiwanese stock market. The results show that the model is effective in stock selection.

In the study conducted by Uygurtürk and Uygurtürk (2014), a model integrated with AHP and VIKOR methods was proposed for hotel selection and evaluation. The selection and evaluation criteria included distance to the airport, number of a la carte restaurants, number of swimming pools, distance to the sea, distance to the city center, and beach length.

Chiu et al. (2013) created a hybrid VIKOR model in order to increase the satisfaction level of customers who buy products from Internet stores in order to form a marketing strategy. This model has been tested with three samples. If customer satisfaction is increased with the model, customers on the Internet will be able to purchase more products, resulting in the need for information-based applications.

Çakır and Perçin (2013) determined the financial performance of 10 logistics companies in a Fortune 500 company list of FORTUNE Turkey magazine in 2011. SAW (Simple Additive Weighting), TOPSIS (Technique for Order Preference by Similarity to Ideal Solution) and VIKOR methods were applied to this dataset. In the study, variables such as owned funds, assets, leverage ratio, number of employees, net sales, and net profit margin were used. The proposed integrated model and performance measurement provided satisfactory results. 
Liu et al. (2013) developed a model based on the VIKOR method for the elimination of health waste in the city of Shanghai, which takes management's views into account. In this model, decision alternatives for burning of health waste, steam sterilization, microwave and storage options were identified. It was determined that comparative results were achieved with the application.

Akyüz's (2012) study of a company that produces furniture pieces has addressed the packaging supplier selection problem with the Fuzzy-VIKOR method and concluded that the two alternatives are conciliatory solutions.

Girubha and Vinodh (2012) looked at material selection in the production of electric car spare parts with a rational model including environmental impact analysis and Fuzzy-VIKOR method. Within the framework of the model and application requirements and material parameters, the results showed that polypropylene material was the best solution.

Özden et al. (2012) measured the financial performances of 6 cement companies that were traded on BIST using the VIKOR method, and they were ranked according to these performances. The company with the highest financial performance in this framework was KONYA Cement, and the company with the lowest financial performance was AFYON Cement.

Yalcin et al. (2012) determined the accounting-based financial performance and value-based financial performance of manufacturing companies in Turkey with Fuzzy-AHP weighing and a TOPSIS-VIKOR integreted model. The performance results obtained by both methods yielded approximately the same result.

Wang and Tzeng (2012) assessed brand marketing by using ANP (Analytic Network Process) and VIKOR methods based on creative brand value for customer satisfaction of 3 electronics manufacturing companies in Taiwan. According to the empirical results, the overall satisfaction is highest in $\mathrm{F}_{2}$ (second firm) company in brand marketing.

Bazzazi et al. (2011) developed a model with a modified VIKOR to determine the preferred equipment for open mines. It was found that the developed model could easily be adapted to the size of mines due to its flexible structure.

Jahan et al. (2011) developed a new VIKOR model in order to evaluate alternative materials in design engineering according to different criteria based on the selection problem objective. With the help of the model proposed in the study, the choice of materials was confirmed and proven with 5 examples, especially in the field of implant application.

Kaya and Kahraman (2011) proposed the integrated VIKOR and AHP approach for the selection of the areas to be forested in Istanbul in terms of numerical and verbal data. Considering the ecological, economic, and socio-political criteria, different alternatives were evaluated, and Ömerli was identified as the most suitable forestation area.

Kuo and Liang (2011) analyzed the service quality of 7 major North Asian International Airports with the integrated VIKOR and GRA model. According to the results of the study, using an integrated model to provide quality of service, including subjective evaluations, is an effective approach.

Liou et al. (2011) developed a modified VIKOR model to improve the service quality of domestic airline companies operating in Taiwan. The proposed model helps decision-makers 
Apan, Öztel \& İslamoğlu | Comparative Empirical Analysis of Financial Failures of Enterprises

understand the difference between the quality of the service offered by the company and the quality of service demanded. For this purpose, managers will be able to make decisions in accordance with clients' needs in order to improve the quality of service requested.

Shemshadi et al. (2011) developed a Fuzzy-VIKOR model that included entropy weighting and quantification of decision-maker considerations in the choice of potential suppliers. The model proposed in the study was proven with application practices and sample applications.

Yang et al. (2009) developed a multi-criteria decision-making model based on VIKOR in assessing increased information security risks. In addition to being effective for new model risk management, teams and managers are helping to understand performance practices.

\section{Data and Methodology}

\section{Data and Sample}

BIST Food and Beverages Index includes 21 companies. For 18 companies, full data was obtained from www.kap.gov.tr for the 2008-2014 period. For this reason, the data of firms listed below are used for empirical analysis.

Table 1: Names of Companies and Their Stock Codes

\begin{tabular}{cll}
\hline & Names of Companies & Stock Codes \\
\hline 1 & ALTINYAĞ KOMBİNALARI A.Ş. & ALYAG \\
2 & ANADOLU EFES BİRACILIK VE MALT SANAYİ A.Ş. & AEFES \\
3 & BANVIT BANDIRMA VİTAMİNLİ YEM SANAYİI A.Ş. & BANVT \\
4 & COCA-COLA İÇECEK A.Ş. & CCOLA \\
5 & ERSU MEYVE VE GIDA SANAYİ A.Ş. & ERSU \\
6 & KENT GIDA MADDELERİ SANAYİ VE TİCARET A.Ş. & KENT \\
7 & KEREVITAŞ GIDA SANAYİ VE TİCARET A.Ş. & KERVT \\
8 & KONFRUT GIDA SANAYİ VE TİCARET A.Ş. & KNFRT \\
9 & KRİSTAL KOLA VE MEŞRUBAT SANAYİ TİCARET A.Ş. & KRSTL \\
10 & MERKO GIDA SANAYİ VE TİCARET A.Ş. & MERKO \\
11 & PENGUEN GIDA SANAYİ A.Ş. & PENGD \\
12 & PINAR ENTEGRE ET VE UN SANAYİİ A.Ş. & PETUN \\
13 & PINAR SU SANAYİ VE TİCARET A.Ş. & PINSU \\
14 & PINAR SÜT MAMÜLLERİ SANAYİ A.Ş. & PNSUT \\
15 & TAT GIDA SANAYİ A.Ş. & TATGD \\
16 & TÜRK TUBORG BİRA VE MALT SANAYİİ A.Ş. & TBORG \\
17 & TUKAŞ GIDA SANAYİ VE TİCARET A.Ş. & TUKAS \\
18 & ÜLKER BİSKÜVİ SANAYİ A.Ş. & ULKER \\
\hline
\end{tabular}

\section{Methodology}

The research data will first be applied to the Altman Z-Score Model, then the VIKOR method will be applied.

\section{Altman Z-Score Methodology}


Altman has improved the Z-Score method based on discriminant analysis. In this framework, five variables describing the financial failure of businesses have been formulated as follows:

$\mathrm{Z}=0.012 \mathrm{X}_{1}+0.014 \mathrm{X}_{2}+0.033 \mathrm{X}_{3}+0.006 \mathrm{X}_{4}+0.999 \mathrm{X}_{5}$

$\mathrm{X}_{1}=$ Working Capital / Total Assets

$\mathrm{X}_{2}=$ Retained Earnings / Total Assets

$\mathrm{X}_{3}=$ Earnings Before Interest and Taxes / Total Assets

$\mathrm{X}_{4}=$ Market Value of Equity / Book Value of Total Liabilities

$\mathrm{X}_{5}=$ Sales / Total Assets

\section{$\mathrm{Z}=\mathrm{Altman} \mathrm{Z}-\mathrm{Score}$}

The sample size of the financial failure studies of enterprises made by Altman consists of 66 firms. In the results of this study, businesses with a Z-value greater than 2.99 would not be settled in a possible economic crisis, and businesses with a Z-value of less than 1.81 would sink in a possible economic crisis (Altman, 1968: 606). In our study, we adapted the modified Altman Z Score model from the research studies implemented by Terzi (2015) and Kulalı (2016)

\section{VIKOR Methodology}

\section{Weighting by Entropy Method}

Entropy has become an important concept in the social sciences as well as the physical sciences (Capocelli \& De Luca, 1973; Nijkamp, 1977). For information theory, entropy has a very useful meaning; namely, thatentropy measures the expected information content of a particular message (Hwang \& Yoon, 1981). In information theory, entropy is a criterion for the amount of uncertainty presented by the discrete probability distribution $P_{i}$ (Jaynes, 1957). This measure of uncertainty is given by Shannon (1948) with the following equation:

$$
S\left(p_{1}, p_{2}, \ldots, p_{n}\right)=-k \sum_{j=1}^{n} p_{j} \ln p_{j} .
$$

Where $\mathrm{k}$ is a constant coefficient. Since the entropy expression is first found in statistical mechanics, it is called the entropy of $p_{i}$ probability distribution. Therefore, the terms "entropy" and "uncertainty" are considered synonymous (Hwang \& Yoon, 1981). When all $p_{i}$ values take $p_{i}=1 / n, S$ has the greatest uncertainty.

Entropy can be used as a tool for evaluating criteria (Nijkamp, 1977; Zeleny, 1974) if given a decision matrix containing information for a certain amount of alternatives. The idea of entropy is particularly useful when examining the contrast between datasets.If a criterion has very similar values to its alternatives, then this criterion is of little importance. Even if all the alternatives have the same values, the criterion is ignored. The entropy method measures the uncertainty in the dataset and measures the variance of the dataset with this uncertainty value.For each criterion, the value of the variation value in the total variance gives the weight value of the criterion. 
The process of determining the weighted value for the criteria by the entropy method is summarized as follows (Hwang \& Yoon, 1981);

Let mxn-dimensional decision matrix of a decision making problem with $m$ alternatives and $n$ criteria be given as follows:

$$
\begin{gathered}
X_{1} \\
D= \\
A_{1} \\
A_{2} \\
\vdots \\
A_{i}
\end{gathered}\left[\begin{array}{cccccc}
x_{11} & x_{12} & \ldots & X_{j} & \ldots & X_{n} \\
x_{21} & x_{22} & \ldots & x_{2 j} & \ldots & x_{1 n} \\
\vdots & \vdots & \vdots & \vdots & \vdots & \vdots \\
A_{m} \\
x_{i 1} & x_{i 2} & \ldots & x_{i j} & \ldots & x_{i n} \\
\vdots & \vdots & \vdots & \vdots & \vdots & \vdots \\
x_{m 1} & x_{m 2} & \ldots & x_{m j} & \ldots & x_{m n}
\end{array}\right]_{m x n}
$$

Where, $x_{i j}$ is the success value of the $i^{\text {th }}$ alternative, in the $j^{\text {th }}$ criterion, $i=1,2, \ldots, m ; j=$ $1,2, \ldots, n$.

The values in row $A_{i}$ indicate the success values according to all the criteria of the $i^{\text {th }}$ alternative, and the values in column $X_{j}$ indicate the success values of all the alternatives according to the $j^{\text {th }}$ criterion.

First of all, since the criteria have different scales, a normalization process is performed in order to make an evaluation. The following equation is used for this:

$r_{i j}=\frac{x_{i j}}{\sum_{p=1}^{m} x_{p j}}, i=1,2, \ldots, m, j=1,2, \ldots, n$

With this equation, $R=\left[r_{i j}\right]_{m \times n}$, the normalized decision matrix is obtained. The uncertainty measure for each criterion, entropy value, is found by the following equation:

$e_{j}=-k \sum_{i=1}^{m} r_{i j} \ln r_{i j}, \quad j=1,2, \ldots, n$

Where $k=\frac{1}{\ln m}$ is a constant coefficient, and $0 \leq e_{j} \leq 1$ are guaranteed. The value of $e_{j}$ is the uncertainty measure of the $j^{\text {th }}$ criterion or, in other words, the entropy value.

Now we can define $d_{j}$ as the degree of diversification for each criterion using the entropy value:

$d_{j}=1-e_{j}, j=1,2, \ldots, n$

The weight values of the criteria are calculated by proportioning the degree of diversification of each criterion to the sum of the degree of diversification:

$$
W_{j}=\frac{d_{j}}{\sum_{p=1}^{n} d_{p}} \quad, \quad j=1,2, \ldots, n .
$$


Where $W_{j}$ is the weight of the $j^{\text {th }}$ criterion, and $\sum_{j=1}^{n} W_{j}=1$ is obvious.

The entropy method is very useful because it is used objectively to determine criteria weights and easy to calculate without the personal opinions of any decision-maker (Erol et al., 2011).

\section{VIKOR Method}

The VIKOR method is a method developed for the optimization of multi-criteria complex systems. This method focuses on selecting and sorting alternatives for problems where there are opposing criteria. The multi-criteria ranking index is based on a partial measure of the ideal solution proximity (Opricovic, 1998).

Assuming that each alternative is evaluated according to each criterion function, it is possible to make a compromise order by measuring the distances of the ideal alternative. Yu (1973) and Zeleny (1974) developed a multi-criteria measure by CP (Compromise Programing) method for consensus ranking using the $L_{p}$-metric as the aggregation function.

Let the set of alternatives consist of $m$ alternatives, shown as $a_{1}, a_{2}, \ldots, a_{m} \cdot f_{i j}$, the criteria function gives the achievment value of the $i^{\text {th }}$ alternative $i=1,2, \ldots, m$, according to $j^{\text {th }}$ criterion $j=1,2, \ldots, n$.

The construction of the VIKOR method starts with the following $L_{p}$ - metric definition (Opricovic, 1998; Opricovic \& Tzeng, 2004):

$L_{p, i}=\left\{\sum_{j=1}^{n}\left[W_{j}\left(f_{j}^{*}-f_{i j}\right) /\left(f_{j}^{*}-f_{j}^{-}\right)\right]^{p}\right\}^{1 / p}, \quad 1 \leq p \leq \infty ; i=1,2, \ldots, m$.

Within the VIKOR method, $L_{p, 1}\left(S_{j}\right.$ in eq. 9$)$ and $L_{p, \infty}\left(R_{j}\right.$ in eq., 10$)$ metrics are used to formulate a ranking measure. The solution acquired respectively by $\min _{J} S_{j}$ and $\min _{J} R_{j}$, with a maximum group utility ("majority" rule), with minimum individual regret of the "opponent".

The compromise solution $F^{c}$ is a feasible solutionthat is the "closest" to the ideal $F^{*}$, and compromise means an agreement established by mutual concessions, as is illustrated in Figure 1 by $\Delta f_{1}=f_{1}^{*}-f_{1}^{c}$ ve $\Delta f_{2}=f_{2}^{*}-f_{2}^{c}$ (Opricovic \& Tzeng, 2004). 


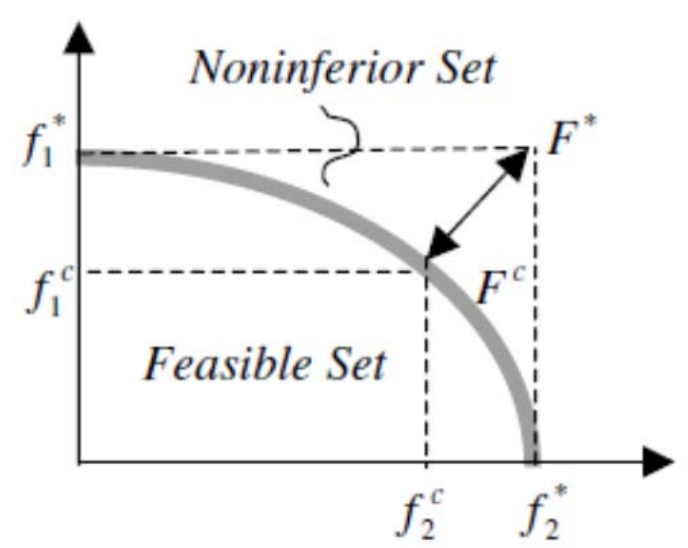

Figure 1. Ideal and compromise solutions (Opricovic \& Tzeng, 2004).

The compromise ranking algorithm VIKOR takes the following steps (Opricovic \& Tzeng, 2004):

(a) Determine the best $f_{j}^{*}$ and the worst $f_{j}^{-}$values of all criterion functions, $j=1,2, \ldots, n$. If the $i$ th function represents a benefit, then:

$f_{j}^{*}=\max _{i} f_{i j} \quad, f_{j}^{-}=\min _{i} f_{i j}$.

If the cost-oriented criterion is defined as the inverse.

(b) $S_{i}$ and $R_{i}, i=1,2, \ldots$, mare calculated as follows:

$S_{i}=\sum_{j=1}^{n} W_{j}\left(f_{j}^{*}-f_{i j}\right) /\left(f_{j}^{*}-f_{j}^{-}\right)$

$R_{i}=\max _{j} W_{j}\left(f_{j}^{*}-f_{i j}\right) /\left(f_{j}^{*}-f_{j}^{-}\right)$

Where, $W_{j}$ is the weight value of the $j$ th criterion.

(c) $Q_{i}, i=1,2, \ldots, m$ is calculated as follows:

$Q_{i}=v\left(S_{i}-S^{*}\right) /\left(S^{-}-S^{*}\right)+(1-v)\left(R_{i}-R^{*}\right) /\left(R^{-}-R^{*}\right)$

Where,

$S^{*}=\min _{i} S_{i}, S^{-}=\max _{i} S_{i}$,

$R^{*}=\min _{i} R_{i}, \quad R^{-}=\max _{i} R_{i}$.

and $v$ is introduced as weight of the strategy of "the majority of criteria" (or "the maximum group utility"'). Here, $v$ is taken as 0.5 .

(d) The alternatives are sorted in descending order according to the values of $S, R$, and $Q$ to obtain three ranking lists. 
(e) The alternative $\left(a^{\prime}\right)$, which is the best (minimum) in terms of $Q$ order, is presented as a compromise solution, providing the following conditions:

C1 . "Acceptable advantage":

$Q\left(a^{\prime \prime}\right)-Q\left(a^{\prime}\right) \geq D Q$

where $a^{\prime \prime}$, is the alternative with second position in the ranking list by $Q ; D Q=1 /(J-1) ; J$ is the number of alternatives.

C2 . "Acceptable stability in decision making":

Alternative $a^{\prime}$, must also be the best-ranked by $S$ or/and $R$. This compromise solution is stable within a decision-making process, which could be: "voting by majority rule" (when $v>0.5$ is needed), or "by consensus" $v \approx 0.5$, or "with veto" ( $v<0.5)$. Here, $v$ is the weight of the decision-making strategy "the majority of criteria" (or "the maximum group utility").

If one of the above conditions is not met, the following compromise solutions are suggested:

- Alternatives $a^{\prime}$ and $a^{\prime \prime}$ if only condition C2 is not satisfied, or

- Alternatives $a^{\prime}, a^{\prime \prime}, \ldots, a^{(M)}$ if condition $\mathrm{C} 1$ is not satisfied; and $a^{(M)}$ is determined by the relation ). $Q\left(a^{(M)}\right)-Q\left(a^{\prime}\right)<D Q$ for maximum $M$ (the positions of these alternatives are "in closeness").

The best alternative is the alternate with the smallest $Q$ value. VIKOR is a useful tool for making very specific decisions, especially if the preferences at the beginning of system design cannot be made by the decision-maker or are unknown.

\section{Empirical Analysis}

\section{Altman Z-Score Application}

The criteria for the Altman Z-Score are presented in Table 2. The Altman Z-Score values (20082014) and the Altman Z-Score Rankings (2008-2014) obtained using these criteria are shown in Tables 3 and 4.

Table 2: The Criteria for Altman Z-Score

\begin{tabular}{ll}
\hline Code & Criterion \\
\hline C1 & Working Capital / Total Assets \\
C2 & Retained Earnings / Total Assets \\
C3 & Earnings Before Interest and Taxes / Total Assets \\
C4 & Market Value of Equity / Book Value of Total Liabilities \\
C5 & Sales / Total Assets \\
\hline
\end{tabular}

Table 3: Altman Z-ScoreValues (2008-2014)

\begin{tabular}{lcccccccc}
\hline & $\mathbf{2 0 0 8}$ & $\mathbf{2 0 0 9}$ & $\mathbf{2 0 1 0}$ & $\mathbf{2 0 1 1}$ & $\mathbf{2 0 1 2}$ & $\mathbf{2 0 1 3}$ & $\mathbf{2 0 1 4}$ & Mean \\
\hline ALYAG & -1.8120 & -0.9911 & -0.4379 & -1.7950 & 1.0083 & 1.5446 & 1.0060 & -0.2110 \\
AEFES & 2.1084 & 2.1714 & 2.2299 & 2.1680 & 2.0018 & 2.0584 & 1.8639 & 2.0860 \\
BANVT & 2.0753 & 2.5154 & 2.9943 & 2.0513 & 1.8159 & 1.7760 & 1.9841 & 2.1732 \\
CCOLA & 2.2108 & 1.8253 & 2.1724 & 2.1919 & 2.3032 & 1.9178 & 2.0497 & 2.0959 \\
ERSU & 2.5301 & 4.4557 & 4.6706 & 2.4139 & 2.6705 & 2.2123 & 1.7833 & 2.9624
\end{tabular}


Apan, Öztel \& İslamoğlu | Comparative Empirical Analysis of Financial Failures of Enterprises

\begin{tabular}{lcccccccc} 
KENT & 2.5372 & 2.7264 & 2.2466 & 2.4094 & 3.0889 & 2.9388 & 3.3770 & 2.7606 \\
KERVT & 0.6811 & 1.0094 & 0.7894 & 0.3154 & 0.3293 & -0.0675 & 0.1458 & 0.4575 \\
KNFRT & 1.4155 & 3.2659 & 2.0715 & 2.5586 & 2.7836 & 2.8725 & 6.3463 & 3.0448 \\
KRSTL & 3.2375 & 5.2848 & 8.9462 & 9.2830 & 9.9364 & 5.2980 & 2.8441 & 6.4043 \\
MERKO & 0.4086 & 0.4408 & -0.2525 & -0.0528 & -0.1267 & 0.0049 & 3.0638 & 0.4980 \\
PENGD & 0.4241 & 0.4338 & 1.8163 & 0.9134 & 0.8069 & 0.9699 & 0.5575 & 0.8460 \\
PETUN & 3.5645 & 3.9700 & 4.1756 & 3.2025 & 3.6647 & 3.6848 & 4.0233 & 3.7550 \\
PINSU & 2.7020 & 3.3531 & 2.9338 & 2.3481 & 2.0637 & 1.3979 & 1.8488 & 2.3782 \\
PNSUT & 3.1019 & 3.6781 & 3.5767 & 3.3825 & 3.4102 & 3.3225 & 3.2631 & 3.3907 \\
TATGD & 1.6053 & 2.1707 & 2.5141 & 2.3228 & 2.2306 & 2.4420 & 2.6830 & 2.2812 \\
TBORG & -1.7961 & -1.3934 & -1.6755 & -1.4520 & -0.2028 & 1.1613 & 1.8175 & -0.5059 \\
TUKAS & -0.2134 & 0.5480 & 0.8389 & -0.4010 & 0.0129 & 0.0721 & -0.7120 & 0.0208 \\
ULKER & 1.3938 & 1.3717 & 1.6520 & 1.3685 & 1.7369 & 1.9805 & 2.2144 & 1.6740 \\
\hline Mean & $\mathbf{1 . 4 5 4 2}$ & $\mathbf{2 . 0 4 6 4}$ & $\mathbf{2 . 2 9 2 4}$ & $\mathbf{1 . 8 4 6 0}$ & $\mathbf{2 . 1 9 6 3}$ & $\mathbf{1 . 9 7 7 0}$ & $\mathbf{2 . 2 3 1 1}$ & $\mathbf{2 . 0 0 6 2}$ \\
\hline
\end{tabular}

For the 2008-2014 period, it was determined that KRSTL is the most successful firm in the Altman Z-Scores, with an average of 6.40429. This was followed by PETUN 3.75503, PNSUT 3.39072, KNFRT 3.04485, and ERSU 2.96237. The second five group of companies are KENT, PINSU, TATGD, BANVT and CCOLA. It has been determined that ALYAG and TBORG firms show the lowest score in this frame with negative scores.

The highest average score of the annual average Altman Z-Score was realized with 2.29235 points in 2010, which may be considered the best year for all companies. This is followed by 2013 with $2.23110,2011$ with 2.19635, and 2009 with 2.04644.The lowest score was 1.45415 in 2008. Here, the effect of the 2008 crisis was seen in all companies.

Table 4: Ranking of companies according to Altman Z-Scores (2008-2014)

\begin{tabular}{lcccccccc}
\hline & $\mathbf{2 0 0 8}$ & $\mathbf{2 0 0 9}$ & $\mathbf{2 0 1 0}$ & $\mathbf{2 0 1 1}$ & $\mathbf{2 0 1 2}$ & $\mathbf{2 0 1 3}$ & $\mathbf{2 0 1 4}$ & Mean Ranking \\
\hline ALYAG & 18 & 17 & 17 & 18 & 13 & 12 & 15 & 13 \\
AEFES & 8 & 9 & 9 & 10 & 10 & 8 & 11 & 9 \\
BANVT & 9 & 8 & 5 & 11 & 11 & 11 & 10 & 9 \\
CCOLA & 7 & 11 & 10 & 9 & 7 & 10 & 9 & 8 \\
ERSU & 6 & 2 & 2 & 5 & 6 & 7 & 14 & 4 \\
KENT & 5 & 7 & 8 & 6 & 4 & 4 & 3 & 12 \\
KERVT & 13 & 13 & 15 & 14 & 15 & 18 & 17 & 6 \\
KNFRT & 11 & 6 & 11 & 4 & 5 & 5 & 1 & 1 \\
KRSTL & 2 & 1 & 1 & 1 & 1 & 1 & 6 & 11 \\
MERKO & 15 & 15 & 16 & 15 & 17 & 17 & 5 & 2 \\
PENGD & 14 & 16 & 12 & 13 & 14 & 15 & 16 & 7 \\
PETUN & 1 & 3 & 3 & 3 & 2 & 2 & 2 & 3 \\
PINSU & 4 & 5 & 6 & 7 & 9 & 13 & 12 & 4 \\
PNSUT & 3 & 4 & 4 & 2 & 3 & 3 & 4 & 7 \\
TATGD & 10 & 10 & 7 & 8 & 8 & 6 & 7 & 13 \\
TBORG & 17 & 18 & 18 & 17 & 18 & 14 & 13 & 10 \\
TUKAS & 16 & 14 & 14 & 16 & 16 & 16 & 18 & 8 \\
ULKER & 12 & 12 & 13 & 12 & 12 & 9 & & 7 \\
\hline
\end{tabular}

When the companies were ranked according to Altman Z-Scores, the best performance according to mean ranking for the period 2008-2014 was exhibited by KRSTL, with PETUN, PNSUT, 
KENT, and ERSU making up the top five. In the second top five group, KNFRT, PINSU, TATGD, CCOLA and AEFES firms took place, with TBORG in last place.

\section{VIKOR Application}

\section{Entropy Weighting}

For VIKOR application, weight values of criteria calculated according to entropy method in 2008-2014 period are presented in Table 5. The magnitude of the weight value reflects the importance of the criterion. When we look at the average weights of all years, criteria 2 and 4 have the highest-weighted values. The reason for this is that the achievement values of firms in these criteria show relatively high differences. According to the entropy method, criterion 5 is at the lowest importance level. In the similar way, the proportionality of the differences in achievement values is relatively low, leading to a lower weight of criterion 5 . While the fixed weights are used in the Altman Z-Score method, the weights in VIKOR method are varied according to the periods.

Table 5: Entropy Weighting Values (2008-2014)

\begin{tabular}{cccccc}
\hline & C1 & C2 & C3 & C4 & 0.21530 \\
\hline 2008 & 0.25513 & 0.34931 & 0.15777 & 0.02249 & 0.04284 \\
2009 & 0.24338 & 0.30797 & 0.12914 & 0.27667 & 0.07194 \\
2010 & 0.16847 & 0.33170 & 0.12242 & 0.34868 & 0.03898 \\
2011 & 0.13944 & 0.27699 & 0.19591 & 0.03417 \\
2012 & 0.13615 & 0.30666 & 0.19309 & 0.23942 & 0.17642 \\
2013 & 0.20833 & 0.32801 & 0.18524 & 0.07120 \\
2014 & 0.21986 & 0.26843 & $\mathbf{0 . 2 7 0 2 7}$ & $\mathbf{0 . 0 4 5 8 0}$ \\
\hline \hline
\end{tabular}

Table 6: The VIKOR Values (2008-2014)

\begin{tabular}{lcccccccc}
\hline & $\mathbf{2 0 0 8}$ & $\mathbf{2 0 0 9}$ & $\mathbf{2 0 1 0}$ & $\mathbf{2 0 1 1}$ & $\mathbf{2 0 1 2}$ & $\mathbf{2 0 1 3}$ & $\mathbf{2 0 1 4}$ & Mean \\
\hline ALYAG & 0.95656 & 0.87957 & 1,00000 & 0.98485 & 0.88651 & 0.61878 & 0.73866 & 0.86642 \\
AEFES & 0.21537 & 0.51970 & 0.53707 & 0.64819 & 0.66776 & 0.31597 & 0.53296 & 0.49100 \\
BANVT & 0.34672 & 0.57900 & 0.52736 & 0.74160 & 0.77365 & 0.57741 & 0.7019 & 0.60681 \\
CCOLA & 0.22477 & 0.57963 & 0.55799 & 0.65753 & 0.64871 & 0.40369 & 0.50621 & 0.51122 \\
ERSU & 0.18263 & 0.17179 & 0.2713 & 0.64836 & 0.58679 & 0.51706 & 0.65639 & 0.43347 \\
KENT & 0.20658 & 0.46306 & 0.57342 & 0.65494 & 0.59397 & 0.26781 & 0.36771 & 0.44678 \\
KERVT & 0.48254 & 0.67880 & 0.68927 & 0.84837 & 0.89289 & 0.75984 & 0.81647 & 0.73831 \\
KNFRT & 0.32942 & 0.43150 & 0.55741 & 0.60197 & 0.58782 & 0.23275 & 0,00000 & 0.39155 \\
KRSTL & 0,00000 & 0,00000 & 0,00000 & 0,00000 & 0,00000 & 0.02892 & 0.48312 & 0.07315 \\
MERKO & 0.47471 & 0.68937 & 0.78074 & 0.85289 & 0.93334 & 0.85303 & 0.78002 & 0.76630 \\
PENGD & 0.41303 & 0.69439 & 0.55783 & 0.75907 & 0.8087 & 0.5299 & 0.69963 & 0.63751 \\
PETUN & 0.07891 & 0.18089 & 0.33561 & 0.53441 & 0.52188 & 0.1013 & 0.45413 & 0.31530 \\
PINSU & 0.15798 & 0.22051 & 0.45449 & 0.6279 & 0.71342 & 0.50355 & 0.59465 & 0.46750 \\
PNSUT & 0.09897 & 0.28199 & 0.41478 & 0.52364 & 0.5584 & 0.19334 & 0.46324 & 0.36205 \\
TATGD & 0.35665 & 0.56792 & 0.55924 & 0.67511 & 0.6834 & 0.37692 & 0.43805 & 0.52247 \\
TBORG & 0.99700 & 0.92767 & 0.95822 & 0.95647 & 0.90188 & 0.85787 & 0.62826 & 0.88962 \\
TUKAS & 0.53677 & 0.67362 & 0.65651 & 0.90106 & 0.88858 & 0.78007 & 0.99019 & 0.77526
\end{tabular}


Apan, Öztel \& İslamoğlu | Comparative Empirical Analysis of Financial Failures of Enterprises

\begin{tabular}{lcccccccc} 
ULKER & 0.31633 & 0.5988 & 0.58546 & 0.72353 & 0.86735 & 0.40887 & 0.47592 & 0.56804 \\
\hline Mean & $\mathbf{0 . 3 5 4 1 6}$ & $\mathbf{0 . 5 0 7 6 8}$ & $\mathbf{0 . 5 5 6 4 8}$ & $\mathbf{0 . 6 8 5 5 5}$ & $\mathbf{0 . 6 9 5 2 8}$ & $\mathbf{0 . 4 6 2 6 2}$ & $\mathbf{0 . 5 7 3 7 5}$ & $\mathbf{0 . 5 4 7 9 3}$ \\
\hline
\end{tabular}

When the average VIKOR values for the period 2008-2014 are examined from Table 6, the best performance of KRSTL company with a score of 0.07315 is shown in all periods. This was followed by PETUN, 0.36205, PNSUT, 0.39155 KNFRT, and 0.43347 ERSU with 0.31530, the best performing companies in the top five. 
AABFJ | Volume 12, no. 1, 2018

Table 7: VIKOR Rankings (2008-2014)

\begin{tabular}{lcccccccc}
\hline & $\mathbf{2 0 0 8}$ & $\mathbf{2 0 0 9}$ & $\mathbf{2 0 1 0}$ & $\mathbf{2 0 1 1}$ & $\mathbf{2 0 1 2}$ & $\mathbf{2 0 1 3}$ & $\mathbf{2 0 1 4}$ & Mean \\
\hline ALYAG & 17 & 17 & 18 & 18 & 14 & 14 & 15 & 17 \\
AEFES & 7 & 8 & 7 & 6 & 8 & 6 & 9 & 8 \\
BANVT & 11 & 10 & 6 & 12 & 11 & 13 & 14 & 12 \\
CCOLA & 8 & 11 & 10 & 9 & 7 & 8 & 8 & 9 \\
ERSU & 5 & 2 & 2 & 7 & 4 & 11 & 12 & 5 \\
KENT & 6 & 7 & 12 & 8 & 6 & 5 & 2 & 6 \\
KERVT & 15 & 14 & 15 & 14 & 16 & 15 & 17 & 14 \\
KNFRT & 10 & 6 & 8 & 4 & 5 & 4 & 1 & 4 \\
KRSTL & 1 & 1 & 1 & 1 & 1 & 1 & 7 & 1 \\
MERKO & 14 & 15 & 16 & 15 & 18 & 17 & 16 & 16 \\
PENGD & 13 & 16 & 9 & 13 & 12 & 12 & 13 & 13 \\
PETUN & 2 & 3 & 3 & 3 & 2 & 2 & 4 & 2 \\
PINSU & 4 & 4 & 5 & 5 & 10 & 10 & 10 & 7 \\
PNSUT & 3 & 5 & 4 & 2 & 3 & 3 & 5 & 3 \\
TATGD & 12 & 9 & 11 & 10 & 9 & 7 & 3 & 10 \\
TBORG & 16 & 13 & 14 & 16 & 15 & 16 & 18 & 15 \\
TUKAS & 18 & 18 & 17 & 17 & 17 & 18 & 11 & 18 \\
ULKER & 9 & 12 & 13 & 11 & 13 & 9 & 6 & 11 \\
\hline
\end{tabular}

A similar situation was observed in the VIKOR rankings in Table 6. The second-best five group consisted of KENT, PINSU, AEFES, CCOLA, and TATGD companies. TUKAS, ALYAG, MERKO, TBORG, and KERVT were the worst performing companies when the averages of all periods were taken into consideration.

Table 8: Altman Z-Score and VIKOR Rankings (2008-2014)

\begin{tabular}{l|cc|cc|cc|cc|cc|cc|cc|}
\hline & \multicolumn{2}{|c|}{$\mathbf{2 0 0 8}$} & \multicolumn{2}{c|}{$\mathbf{2 0 0 9}$} & \multicolumn{2}{c|}{$\mathbf{2 0 1 0}$} & \multicolumn{2}{c|}{$\mathbf{2 0 1 1}$} & \multicolumn{2}{c|}{$\mathbf{2 0 1 2}$} & \multicolumn{2}{c|}{$\mathbf{2 0 1 3}$} & \multicolumn{2}{c|}{$\mathbf{2 0 1 4}$} \\
& $\mathbf{A}$ & $\mathbf{V}$ & $\mathbf{A}$ & $\mathbf{V}$ & $\mathbf{A}$ & $\mathbf{V}$ & $\mathbf{A}$ & $\mathbf{V}$ & $\mathbf{A}$ & $\mathbf{V}$ & $\mathbf{A}$ & $\mathbf{V}$ & $\mathbf{A}$ & $\mathbf{V}$ \\
\hline ALYAG & 18 & 17 & 17 & 17 & 17 & 18 & 18 & 18 & 13 & 14 & 12 & 14 & 15 & 15 \\
AEFES & 8 & 7 & 9 & 8 & 9 & 7 & 10 & 6 & 10 & 8 & 8 & 6 & 11 & 9 \\
BANVT & 9 & 11 & 8 & 10 & 5 & 6 & 11 & 12 & 11 & 11 & 11 & 13 & 10 & 14 \\
CCOLA & 7 & 8 & 11 & 11 & 10 & 10 & 9 & 9 & 7 & 7 & 10 & 8 & 9 & 8 \\
ERSU & 6 & 5 & 2 & 2 & 2 & 2 & 5 & 7 & 6 & 4 & 7 & 11 & 14 & 12 \\
KENT & 5 & 6 & 7 & 7 & 8 & 12 & 6 & 8 & 4 & 6 & 4 & 5 & 3 & 2 \\
KERVT & 13 & 15 & 13 & 14 & 15 & 15 & 14 & 14 & 15 & 16 & 18 & 15 & 17 & 17 \\
KNFRT & 11 & 10 & 6 & 6 & 11 & 8 & 4 & 4 & 5 & 5 & 5 & 4 & 1 & 1 \\
KRSTL & 2 & 1 & 1 & 1 & 1 & 1 & 1 & 1 & 1 & 1 & 1 & 1 & 6 & 7 \\
MERKO & 15 & 14 & 15 & 15 & 16 & 16 & 15 & 15 & 17 & 18 & 17 & 17 & 5 & 16 \\
PENGD & 14 & 13 & 16 & 16 & 12 & 9 & 13 & 13 & 14 & 12 & 15 & 12 & 16 & 13 \\
PETUN & 1 & 2 & 3 & 3 & 3 & 3 & 3 & 3 & 2 & 2 & 2 & 2 & 2 & 4 \\
PINSU & 4 & 4 & 5 & 4 & 6 & 5 & 7 & 5 & 9 & 10 & 13 & 10 & 12 & 10 \\
PNSUT & 3 & 3 & 4 & 5 & 4 & 4 & 2 & 2 & 3 & 3 & 3 & 3 & 4 & 5 \\
TATGD & 10 & 12 & 10 & 9 & 7 & 11 & 8 & 10 & 8 & 9 & 6 & 7 & 7 & 3 \\
TBORG & 17 & 18 & 18 & 18 & 18 & 17 & 17 & 17 & 18 & 17 & 14 & 18 & 13 & 11 \\
TUKAS & 16 & 16 & 14 & 13 & 14 & 14 & 16 & 16 & 16 & 15 & 16 & 16 & 18 & 18 \\
ULKER & 12 & 9 & 12 & 12 & 13 & 13 & 12 & 11 & 12 & 13 & 9 & 9 & 8 & 6 \\
\hline
\end{tabular}

A:Altman Z-Score Ranking, V:VIKOR Ranking 
Apan, Öztel \& İslamoğlu | Comparative Empirical Analysis of Financial Failures of Enterprises

Table 9: Spearman rank correlations for VIKOR and Altman Z-Scores Rankings

\begin{tabular}{|c|c|c|c|c|c|c|c|c|c|c|c|c|c|c|}
\hline & A2008 & V2008 & A2009 & V2009 & A2010 & V2010 & A2011 & V2011 & A2012 & V2012 & A2013 & V2013 & A2014 & V2014 \\
\hline \multirow{2}{*}{ A2008 } & 1.0000 & $0.967 * *$ & $0.917 * *$ & $0.909 * *$ & $0.911^{* *}$ & $0.860 * *$ & $0.913 * *$ & $0.911^{* *}$ & $0.886^{* *}$ & $0.872^{* *}$ & $0.759 * *$ & $0.814^{* *}$ & $0.548^{*}$ & $0.589 *$ \\
\hline & & 0.0000 & 0.0000 & 0.0000 & 0.0000 & 0.0000 & 0.0000 & 0.0000 & 0.0000 & 0.0000 & 0.0003 & 0.0000 & 0.0186 & 0.0101 \\
\hline \multirow{2}{*}{ V2008 } & $0.967 * *$ & 1.0000 & $0.915^{* *}$ & $0.917 * *$ & $0.882^{* *}$ & $0.872 * *$ & $0.911 * *$ & $0.936^{* *}$ & $0.880 * *$ & $0.878^{* *}$ & $0.775^{* *}$ & $0.837 * *$ & $0.554 *$ & $0.593 * *$ \\
\hline & 0.0000 & & 0.0000 & 0.0000 & 0.0000 & 0.0000 & 0.0000 & 0.0000 & 0.0000 & 0.0000 & 0.0002 & 0.0000 & 0.0170 & 0.0094 \\
\hline \multirow{2}{*}{ A2009 } & $0.917 * *$ & $0.915^{* *}$ & 1.0000 & $0.990^{* *}$ & $0.930^{* *}$ & $0.901^{* *}$ & $0.942 * *$ & $0.917 * *$ & $0.891 * *$ & $0.891^{* *}$ & $0.781^{* *}$ & $0.779 * *$ & $0.527 *$ & $0.548^{*}$ \\
\hline & 0.0000 & 0.0000 & & 0.0000 & 0.0000 & 0.0000 & 0.0000 & 0.0000 & 0.0000 & 0.0000 & 0.0001 & 0.0001 & 0.0245 & 0.0186 \\
\hline \multirow{2}{*}{ V2009 } & $0.909 * *$ & $0.917^{* *}$ & $0.990 * *$ & 1.0000 & $0.915^{* *}$ & $0.889 * *$ & $0.936^{* *}$ & $0.924 * *$ & $0.884 * *$ & $0.889^{* *}$ & $0.781 * *$ & $0.789^{* *}$ & $0.513^{*}$ & $0.569 *$ \\
\hline & 0.0000 & 0.0000 & 0.0000 & & 0.0000 & 0.0000 & 0.0000 & 0.0000 & 0.0000 & 0.0000 & 0.0001 & 0.0001 & 0.0295 & 0.0138 \\
\hline \multirow{2}{*}{ A2010 } & $0.911 * *$ & $0.882 * *$ & $0.930 * *$ & $0.915^{* *}$ & 1.0000 & $0.940 * *$ & $0.880 * *$ & $0.835^{* *}$ & $0.843 * *$ & $0.868^{* *}$ & $0.746^{* *}$ & $0.728 * *$ & 0.4097 & 0.470 * \\
\hline & 0.0000 & 0.0000 & 0.0000 & 0.0000 & & 0.0000 & 0.0000 & 0.0000 & 0.0000 & 0.0000 & 0.0004 & 0.0006 & 0.0913 & 0.0493 \\
\hline \multirow{2}{*}{ V2010 } & $0.860 * *$ & $0.872 * *$ & $0.901 * *$ & $0.889^{* *}$ & $0.940^{* *}$ & 1.0000 & $0.860 * *$ & $0.870^{* *}$ & $0.777 * *$ & $0.849^{* *}$ & $0.664 * *$ & $0.701^{* *}$ & 0.3416 & 0.4035 \\
\hline & 0.0000 & 0.0000 & 0.0000 & 0.0000 & 0.0000 & & 0.0000 & 0.0000 & 0.0001 & 0.0000 & 0.0027 & 0.0012 & 0.1653 & 0.0968 \\
\hline \multirow{2}{*}{ A2011 } & $0.913^{* *}$ & $0.911^{* *}$ & $0.942 * *$ & $0.936^{* *}$ & $0.880^{* *}$ & $0.860 * *$ & 1.0000 & $0.965^{* *}$ & $0.950 * *$ & $0.944^{* *}$ & $0.862 * *$ & $0.895^{* *}$ & $0.670^{* *}$ & $0.732 * *$ \\
\hline & 0.0000 & 0.0000 & 0.0000 & 0.0000 & 0.0000 & 0.0000 & & 0.0000 & 0.0000 & 0.0000 & 0.0000 & 0.0000 & 0.0024 & 0.0006 \\
\hline \multirow{2}{*}{ V2011 } & $0.911 * *$ & $0.936^{* *}$ & $0.917 * *$ & $0.924 * *$ & $0.835^{* *}$ & $0.870 * *$ & $0.965^{* *}$ & 1.0000 & $0.903 * *$ & $0.911^{* *}$ & $0.816^{* *}$ & $0.907 * *$ & $0.633^{* *}$ & $0.703 * *$ \\
\hline & 0.0000 & 0.0000 & 0.0000 & 0.0000 & 0.0000 & 0.0000 & 0.0000 & & 0.0000 & 0.0000 & 0.0000 & 0.0000 & 0.0048 & 0.0011 \\
\hline \multirow{2}{*}{ A2012 } & $0.886^{* *}$ & $0.880^{* *}$ & $0.891 * *$ & $0.884^{* *}$ & $0.843^{* *}$ & $0.777 * *$ & $0.950 * *$ & $0.903 * *$ & 1.0000 & $0.975^{* *}$ & $0.928^{* *}$ & $0.934 * *$ & $0.666^{* *}$ & $0.756^{* *}$ \\
\hline & 0.0000 & 0.0000 & 0.0000 & 0.0000 & 0.0000 & 0.0001 & 0.0000 & 0.0000 & & 0.0000 & 0.0000 & 0.0000 & 0.0026 & 0.0003 \\
\hline \multirow{2}{*}{ V2012 } & $0.872 * *$ & $0.878^{* *}$ & $0.891^{* *}$ & $0.889^{* *}$ & $0.868^{* *}$ & $0.849 * *$ & $0.944 * *$ & $0.911 * *$ & $0.975 * *$ & 1.0000 & $0.913^{* *}$ & $0.913^{* *}$ & $0.577 *$ & $0.703 * *$ \\
\hline & 0.0000 & 0.0000 & 0.0000 & 0.0000 & 0.0000 & 0.0000 & 0.0000 & 0.0000 & 0.0000 & & 0.0000 & 0.0000 & 0.0122 & 0.0011 \\
\hline \multirow{2}{*}{ A2013 } & $0.759 * *$ & $0.775^{* *}$ & $0.781 * *$ & $0.781^{* *}$ & $0.746^{* *}$ & $0.664 * *$ & $0.862 * *$ & $0.816^{* *}$ & $0.928 * *$ & $0.913^{* *}$ & 1.0000 & $0.920^{* *}$ & $0.725^{* *}$ & $0.837 * *$ \\
\hline & 0.0003 & 0.0002 & 0.0001 & 0.0001 & 0.0004 & 0.0027 & 0.0000 & 0.0000 & 0.0000 & 0.0000 & & 0.0000 & 0.0007 & 0.0000 \\
\hline \multirow{2}{*}{ V2013 } & $0.814^{* *}$ & $0.837^{* *}$ & $0.779 * *$ & $0.789 * *$ & $0.728^{* *}$ & $0.701 * *$ & $0.895^{* *}$ & $0.907^{* *}$ & $0.934 * *$ & $0.913^{* *}$ & $0.920 * *$ & 1.0000 & $0.709^{* *}$ & $0.837 * *$ \\
\hline & 0.0000 & 0.0000 & 0.0001 & 0.0001 & 0.0006 & 0.0012 & 0.0000 & 0.0000 & 0.0000 & 0.0000 & 0.0000 & & 0.0010 & 0.0000 \\
\hline \multirow[b]{2}{*}{ A2014 } & $0.548^{*}$ & $0.554^{*}$ & $0.527^{*}$ & $0.513^{*}$ & 0.4097 & 0.3416 & $0.670 * *$ & $0.633 * *$ & $0.666^{* *}$ & $0.577^{*}$ & $0.725 * *$ & $0.709 * *$ & 1.0000 & $0.804^{* *}$ \\
\hline & 0.0186 & 0.0170 & 0.0245 & 0.0295 & 0.0913 & 0.1653 & 0.0024 & 0.0048 & 0.0026 & 0.0122 & 0.0007 & 0.0010 & & 0.0001 \\
\hline \multirow{2}{*}{ V2014 } & $0.589 *$ & $0.593 * *$ & $0.548^{*}$ & $0.569^{*}$ & $0.470^{*}$ & 0.4035 & $0.732 * *$ & $0.703^{* *}$ & $0.756^{* *}$ & $0.703^{* *}$ & $0.837^{* *}$ & $0.837 * *$ & $0.804 * *$ & 1.0000 \\
\hline & 0.0101 & 0.0094 & 0.0186 & 0.0138 & 0.0493 & 0.0968 & 0.0006 & 0.0011 & 0.0003 & 0.0011 & 0.0000 & 0.0000 & 0.0001 & \\
\hline
\end{tabular}

**. Correlation is significant at the 0.01 level (2-tailed). A:Altman Z-Score Ranking, V:Vikor Ranking

*. Correlation is significant at the 0.05 level (2-tailed).

In Table 8, comparisons were made for the 2008-2014 period, with rankings obtained by the Altman Z-Score and VIKOR methods. Here, it is observed that the two methods give very similar results. The best way to measure the similarity between rankings is undoubtedly Spearman's rank correlation. High correlation value indicates high similarity. Spearman's rank correlation between the two method rankings given in Table 9 shows that the results of both methods are very close. Correlations are 0.80 in 2014 and 0.90 in all other periods. Such high correlations clearly show that the two methods produce similar results. It is outside the purpose of this work to put forth the reasons for this similarity. But the similarity shows that VIKOR method can be used as an alternative in the bankruptcy analysis.

\section{Conclusion}

The empirical analysis of 18 firms in the BIST-Food and Beverage Index for 2008-2014 period data were conducted using a comparative approach based on the Altman Z-Score and VIKOR method. By combining the results of the two methods, general results were obtained. According to this approach, the KRSTL firm has been ranked first in terms of both methods and average ranking. The low performance of KRSTL in 2014 has remained within the relatively good performance of the past years. PETUN, which performed second, displayed a balanced performance in all years. Overall, there was no fluctuation in performance. PNSUT, the third company, also displayed a balanced performance. The KNFRT firm, which ranks fourth, settled in first place in both methods in 2014. However, low and unstable performance results in the past few years have affected the overall average in a negative direction. It has been determined that KNFRT will perform more successfully in 2014 than in previous years. 
The VIKOR method, which yields results similar to those of the Altman Z-Score, is an alternative and complementary method for bankruptcy analysis. This study shows that the VIKOR method can be used reliably in bankruptcy analysis, and this study will be a pioneering work in the use of VIKOR method in bankruptcy analysis to be carried out in other sectors as well.

This study has shown that other MCDM methods are powerful tools that can be used in financial failure analysis.

\section{References:}

Akay, E.,C., \& Gokdemir, T. (2015). The Comparision of the Financial Failure with Artificial Neural Network and Logit Models. Journal of Business, Economics \& Finance, Vol.4, No.3, pp. 383-400. https://doi.org/10.17261/Pressacademia.2015313060

Akyüz, G. (2012). Bulanık VIKOR Yöntemi İle Tedarikçi Seçimi. Atatürk Üniversitesi İktisadi ve İdari Bilimler Dergisi, Vol.26, No.1, pp. 197-214.

Akkaya, Göktuğ, C., Erhan, Demirelli \& Yakut, Ümit, H. (2009). İșletmelerde Finansal Başarısızlık Tahminlemesi: Yapay Sinir Ağları Modeli İle İMKB Üzerine Bir Uygulama. Eskişehir Osmangazi Üniversitesi Sosyal Bilimler Dergisi, Vol.10, No.2, pp. 187-216.

Almamy, J., John, A., \& Ngwa, L.,N. (2016). An evaluation of Altman's Z-score using cash ratio to predict corporate failure amid the recent financial crisis: Evidence from the UK. Journal of Corporate Finance, No.36, pp. 278-285. https://doi.org/10.1016/j.jcorpfin.2015.12.009

Altman, Edward I. (1968). Financial Ratios, Discriminant Analysis and the Prediction of Corporate Bankruptcy. The Journal of Finance, Vol.23, No.4, pp. 589-609. https://doi.org/10.1111/j.1540-6261.1968.tb00843.x

Bağcı, E. (2015). Türkiye Tekstil ve Hazır Giyim Sektörünün Finansal Durum Analizi. Marmara Üniversitesi İktisadi ve İdari Bilimler Dergisi, Vol.37, No.2, pp. 83-100. https://doi.org/10.14780/iibd.83811

Baş, M., \& Çakmak, Z. (2012). Gri İlişkisel Analiz ve Lojistik Regresyon Analizi İle İşletmelerde Finansal Başarısızlığın Belirlenmesi ve Bir Uygulama. Anadolu Üniversitesi Sosyal Bilimler Dergisi, Vol.12, No.3, pp. 63-82.

Bazzazi, A.,A., Osanloo, M., \& Karimi, B.(2011). Deriving preference order of open pit mines equipment through MADM methods: Application of modified VIKOR method. Expert Systems with Applications, No.38, pp. 2550-2556. https://doi.org/10.1016/i.eswa.2010.08.043

Beaver, W. H. (1966). Financial ratios as predictors of failure. Journal of accounting research, Vol.4, pp. 71-111. https://doi.org/10.2307/2490171

Bozkurt, İ.(2014). İflas Olasılığı İle Sistematik Risk İlişkisinin İncelenmesi ve Etkin İflas Göstergesi Modellerinin Tespiti: BİST'de Ampirik Bir Uygulama. Süleyman Demirel Üniversitesi İktisadi ve İdari Bilimler Fakültesi Dergisi, Vol.19, No.4, pp. 127-142. 
Apan, Öztel \& İslamoğlu | Comparative Empirical Analysis of Financial Failures of Enterprises

Cengiz, D.,T., Münevver, T., Kalkan, Seda, B., \& Köse, İ. (2015). Türkiye'deki İşletmelerin Finansal Başarısızlığının Faktör Analizi ve Diskriminant Analizi İle İncelenmesi. İstanbul Üniversitesi İktisat Fakültesi Ekonometri ve İstatistik Dergisi, Vol.23, pp. 6279.

Chiu, W.,Y., Tzeng, G.,H., \& Li, H.,L., (2013). A nem hybrid MCDM model combining DANP with VIKOR to improve e-store business. Knowledge-Based Systems, No.37, pp. 48-61. https://doi.org/10.1016/i.knosys.2012.06.017

Civan, M, \& Dayı, F, (2014). Altman Z Skoru ve Yapay Sinir Ağları Modeli İle Sağlık İşletmelerinde Finansal Başarısızlık Tahmini. Akademik Bakış Dergisi, No.41, http://www.akademikbakis.org/?sayfa=dergiayrinti\&no=225\&icerik=altman-z-skoru-veyapay-sinir-agi-modeli-ile-saglik-isletmelerinde-finansal-basarisizliktahmini\&kategori=finans-yonetimi (17.11.2016)

Capocelli, R. M., \& De Luca, A. (1973). Fuzzy sets and decision theory. Information and control, Vol.23, No.5, pp. 446-473. https://doi.org/10.1016/S0019-9958(73)80009-9

Çakır, S., \& Perçin, S.(2013). Çok Kriterli Karar Verme Teknikleriyle Lojistik Firmalarında Performans Ölçümü. Ege Akademik Bakış, Vol.13, No.4, pp. 449-459. https://doi.org/10.21121/eab.2013418079

Çevik, E., \& Gökşen, Y. (2016). Yatırım Projelerinin Değerlendirilmesinde AHP-VIKOR Entegrasyonu İle Bir Karar Destek Sistemi Önerisi. Ege Stratejik Araştırmalar Dergisi, Vol.7, No.2, pp. 219-235. https://doi.org/10.18354/esam.32181

Demircanlı, B., \& Kundakcı, N. (2015). Futbolcu Transfelerinin AHP ve VIKOR Yöntemlerine Dayalı Bütünleşik Yaklaşım İle Değerlendirilmesi. Dokuz Eylül Üniversitesi İktisadi ve İdari Bilimler Fakültesi Dergisi, Vol.30, No.2, pp. 105-129.

Erol, I., Sencer, S., \& Sari, R. (2011). A new fuzzy multi-criteria framework for measuring sustainability performance of a supply chain. Ecological Economics, Vol.70, No.6, pp. 1088-1100. doi: https://doi.org/10.1016/i.ecolecon.2011.01.001

Fisher, R. A. (1936). The use of multiple measurements in taxonomic problems. Annals of eugenics, Vol.7, No.2, pp. 179-188. https://doi.org/10.1111/j.1469-1809.1936.tb02137.x

Girubha, R.,J., \&Vinodh, S.(2012). Application of fuzzy VIKOR and environmental impact analysis for material selection of an automotive component. Materials and Design, No.37, pp. 478-486. https://doi.org/10.1016/j.matdes.2012.01.022

Grice, J.,S., \& Ingram, R.,W., (2001). Tests of the generalizability of Altman's bankruptcy prediction model. Journal of Business Research, No.54, pp. 53-61. https://doi.org/10.1016/S0148-2963(00)00126-0

Hwang, C.-L., \& Yoon, K. (1981). Lecture Notes in Economics and Mathematical Systems: Multiple Attribute Decision Making: Methods and Appllication: Springer Verlag.

İskenderoğlu, Ö., \& Karakozak, Ö. (2013). 2008 Küresel Finansal Krizin Finansal Oranlar Üzerine Etkisi: BİST'de İşlem Gören İmalat İşletmeleri Üzerine Bir Uygulama. Dokuz Eylül Üniversitesi İktisadi ve İdari Bilimler Fakültesi Dergisi, Vol.28, No.2, pp. 99-129. 
Jahan, A., Mustapha, F., Ismail, Md., Y., Sapuan, S., M., \& Bahraminasab, M. (2011). A comprehensive VIKOR method for material selection. Materials and Design, No.32, pp. 1215-1221. https://doi.org/10.1016/j.matdes.2010.10.015

Jaynes, E. T. (1957). Information theory and statistical mechanics. The Physical Review, Vol.106, No.4, pp. 620-630. https://doi.org/10.1103/PhysRev.106.620 https://doi.org/10.1103/PhysRev.108.171

Kara, İ., \& Ecer, F. (2016). AHP-VIKOR Entegre Yöntemi İle Tedarikçi Seçimi: Tekstil Sektörü Uygulaması. Dokuz Eylül Üniversitesi Sosyal Bilimler Enstitüsü Dergisi, Vol.18, No.2, pp. 255-272. https://doi.org/10.16953/deusbed.78956

Kaya, T., \& Kahraman, C. (2011). Fuzzy multiple criteria forestry decision making based on an integrated VIKOR and AHP approach. Expert Systems with Applications, No.38, pp. 7326-7333. https://doi.org/10.1016/j.eswa.2010.12.003

Kaygın, C.,Y., Alper, T., \& Yazarkan, H. (2016). İşletmelerin Finansal Başarılı ve Başarısız Olma Durumlarının Veri Madenciliği ve Lojistik Regresyon Analizi İle Tahmin Edilebilirliği. Ege Akademik Bakış, Vol.16, No.1, pp. 147-159.

Kılıç, Y., \& Seyrek, İbrahim H. (2012). Finansal Başarısızlık Tahmininde Yapay Sinir Ağlarının Kullanılması: İmalat Sektöründe Bir Uygulama. pp.1-15. (1.International Symposium on Accounting and Finance) https://www.researchgate.net/publication/296705043_Finansal_Basarisizlik_Tahminin de_Yapay_Sinir_Aglarinin_Kullanilmasi_Imalat_Sektorunde_Bir_Uygulama, (8.11.2016)

Ko, Y.C., Hamido, F., \& Li, T. (2016). An evidential analysis of Alman's Z-score for financial prediction: Case study on solar energy companies. Applied Soft Computing, (https://doi.org/10.1016/j.asoc.2016.09.050.)

Kulalı, İ. (2016). Altman Z-Skor Modelinin BİST Şirketlerinin Finansal Başarısızlık Riskinin Tahmin Edilmesinde Uygulanması. Uluslararası Yönetim İktisat ve İşletme Dergisi, Vol.12, No.27, pp. 283-291.

Kuo, M.,S., \& Liang, G., S. (2011). Combining VIKOR with GRA techniques to evaluate service quality of airports under fuzzy environment. Expert Systems with Applications, No.38, pp. 1304-1312. https://doi.org/10.1016/j.eswa.2010.07.003

Liou, J.,J.,H., Tsai, C.,Y., Lin, R.,H., \& Tzeng, G.,H., (2011). A modified VIKOR multiplecriteria decision method for improving domestic airlines service quality. Journal of Air Transport Mangement, No.17, pp. 57-61. https://doi.org/10.1016/i.jairtraman.2010.03.004

Liu, H.,C., You, J.,X., You, X.,Y., \& Shan, M.,M., (2015). A novel approach for failure mode and effects analysis using combining weighting and fuzzy VIKOR method. Applied Soft Computing, No.28, pp. 579-588. https://doi.org/10.1016/j.asoc.2014.11.036

Liu, H.,C., Wu, J., \& Li, P. (2013). Assessment of health-care waste disposal methods using a VIKOR-based fuzzy multi-criteria decision making method. Waste Management, No.33, pp. 2744-2751. https://doi.org/10.1016/j.wasman.2013.08.006 
Apan, Öztel \& İslamoğlu | Comparative Empirical Analysis of Financial Failures of Enterprises

Mişu, N.,B., \& Codreanu, E.,S. (2014). Analysis and Prediction of the Bankruptcy Risk in Romanian Building Sector Companies. Ekonomika, Vol.93, No.2, pp. 131146.(Erişim:14.11.2016)

Nijkamp, P. (1977). Stochastic quantitative and qualitative multicriteria analysis for environmental design. Papers in Regional Science, Vol.39, No.1, pp. 175-199. https://doi.org/10.1007/BF01936213 https://doi.org/10.1111/j.1435-5597.1977.tb01006.x

Opricovic, S., \& Tzeng, G.-H. (2004). Compromise solution by MCDM methods: A comparative analysis of VIKOR and TOPSIS. European Journal of Operational Research, Vol.156, No.2, pp. 445-455. https://doi.org/10.1016/S0377-2217(03)00020-1

Opricovic, S. (1998). Multicriteria optimization of civil engineering systems. Faculty of Civil Engineering, Belgrade, Vol.2, No.1, pp. 5-21.

Önder, E., \& Yıldırım, B., F. (2014). VIKOR Method For Ranking Logistic Villages in Turkey. Yönetim ve Ekonomi Araştırmaları Dergisi, No.23, pp. 293-314.

Özdemir, Fevzi, S. (2014). Halka Açık ve Halka Açık Olmayan İşletmeler Yönüyle Tekdüzen Muhasebe Sistemi ve Altman Z Skor Modellerinin Uygulanabilirliği. Ege Akademik Bakış Dergisi, Vol.14, No.1, pp. 147-161.

Özden, Ü.,H., Özlem, D., Başarır \& Kalkan, Seda, B. (2012). İMKB'de İşlem Gören Çimento Sektöründeki Şirketlerin Finansal Performanslarının VIKOR Yöntemi İle Sıralanması. İstanbul Üniversitesi İktisat Fakültesi Ekonometri ve İstatistik Dergisi, No.17, pp. 23-44.

Poyraz, E., \& Uçma, T. (2006). Türkiye'de Faaliyet Gösteren İhracatçı Sektörlerin Mali Kriz Ortamlarında Finansal Başarısızlıklarının Altman (Z-Score) Modeli Yardımıyla Ölçülmesi. Muhasebe ve Finansman Dergisi, Ekim 2006 No.32.

Rybárová, D., Braunová, M., \& Jantošová, L. (2016). Analysis of the Construction Industry in the Slovak Republic by Bankruptcy Model. Procedia - Social and Behavioral Sciences, No.230, pp. 298-306.

Rezaie, K., Ramiyani, S.,S., Shirkouki, S.,N.,ve Badizadeh, A. (2014). Evaluating performance of İranian cement firms using an intgrated fuzzy AHP-VIKOR method, Applied Mathematical Modelling, No.38, pp. 5033-5046. https://doi.org/10.1016/j.apm.2014.04.003

Rim, E.,K., \& Roy, A.,B., (2014). Classifying Manufacturing Firms in Lebanon: An Application of Altman's Model. Procedia-Social and Behavioral Sciences, No.109, pp. 11-18. https://doi.org/10.1016/j.sbspro.2013.12.413

Rostamzadeh, R., Govindan, K., Esmaeili, A., \& Sabaghi, M. (2015). Application of fuzzy VIKOR for evaluation of green supply chain management practices. Ecological Indicators, No.49, pp. 188-203. https://doi.org/10.1016/i.ecolind.2014.09.045

Selimoğlu, S., \& Orhan, A. (2015). Finansal Başarızılığın Oran Analizi ve Diskriminat Analizi Kullanılarak Ölçümlenmesi:BİST'de İşlem Gören Dokuma, Giyim Eşyası ve Deri İşletmeleri Üzerine Bir Araştırma. Muhasebe ve Finansman Dergisi, Nisan 2015 No.66, pp. 21-40. 
Shannon, C. (1948). A mathematical theory of communication, The Bell System Technical Journal, No.27: pp. 379-423 and 623-656. Mathematical Reviews (MathSciNet): MR10, 133e. https://doi.org/10.1002/i.1538-7305.1948.tb00917.x https://doi.org/10.1002/j.1538-7305.1948.tb01338.x

Shemshadi, A., Shirazi, H., Toreihi, M., \& Tarokh, M.,J., (2011). A fuzzy VIKOR method for supplier selection based on entropy measure for objective weighting. Expert Systems with Applications, No.38, pp. 12160-12167. https://doi.org/10.1016/i.eswa.2011.03.027

Shen, K.,Y., Yan, M.,R.,\& Tzeng, G.,H. (2014). Combining VIKOR-DANP model for glamor stock selection and stock performance improvement. Knowledge-Based Systems, No.58, pp. 86-97. https://doi.org/10.1016/i.knosys.2013.07.023

Terzi, S. (2011). Finansal Rasyolar Yardımıyla Finansal Başarısızlık Tahmini: Gıda Sektöründe Ampirik Bir Araştırma. Çukurova Üniversitesi İktisadi ve İdari Bilimler Fakültesi Dergisi, Vol.15, No.1, pp. 1-18.

Toraman, C., \& Karaca, C. (2016). Kimya Endüstrisinde Faaliyet Gösteren Firmalar Üzerinde Mali Başarısızlık Tahmini: Borsa İstanbul'da Bir Uygulama. Muhasebe ve Finansman Dergisi, Nisan 2016, No.70, pp. 111-128. https://doi.org/10.25095/mufad.396683

Uygurtürk, H., \& Uygurtürk, H. (2014). Bütünleşik AHS-VIKOR İle Otel Seçimi. Ekonomik ve Sosyal Araştırmalar Dergisi, Vol.10, No.2, pp. 103-117.

Wang, Y.,L., \& Tzeng, G., H. (2012). Brand marketing for creating brand value based on a MCDM model combining DEMATEL with ANP and VIKOR methods. Expert Systems with Applications, No.39, pp. 5600-5615. https://doi.org/10.1016/j.eswa.2011.11.057

Yalcin, N., Bayraktaroglu, A., \& Kahraman, C. (2012). Application of fuzzy multi-criteria decision making merhods for financial performance evaluation of Turkish manufacturing industries. Expert Systems with Applications, No.39, pp. 350-364. https://doi.org/10.1016/j.eswa.2011.07.024

Yang, Y.,P.,O., Sheih, H.,M., Leu, J.,D., \& Tzeng, G.,H. (2009). A VIKOR-Based Multiple Criteria Decision Method For Improving Information Security Risk. International Journal of Information Technology \& Decision Making, Vol.8, No.2, pp. 267-287. https://doi.org/10.1142/S0219622009003375

Yıldız, A. (2014). Kurumsal Yönetim Endeksi ve Altman Z Skoruna Dayalı Lojistik Regresyon Yöntemiyle Şirketlerin Kredi Derecelendirmesi. Süleyman Demirel Üniversitesi İktisadi ve İdari Bilimler Fakültesi Dergisi, Vol.19, No.3, pp. 71-89.

Yılmaz, H., \& Yıldıran, M. (2015). Borsada İşlem Gören İşletmelerde Mali Başarısızlık Tahmini: Altman Modeli'nin BİST Uygulaması. Aksaray Üniversitesi İktisadi ve İdari Bilimler Fakültesi Dergisi, Vol.7, No.3, pp. 43-49.

Yi, Wang (2012). Z-score Model on Financial Crisis Early-Warning of Listed Real Estate Companies in China: a Financial Engineering Perspective. Systems Engineering Procedia, No.3, pp. 153-157. https://doi.org/10.1016/i.sepro.2011.11.021

Yu, P.-L. (1973). A class of solutions for group decision problems. Management science, Vol.19, No.8, pp. 936-946. https://doi.org/10.1287/mnsc.19.8.936 
Apan, Öztel \& İslamoğlu | Comparative Empirical Analysis of Financial Failures of Enterprises

Zeytinoğlu, E., \& Akarım, Y., D. (2013). Financial Failure Prediction Using Financial Ratios:

An Empirical Application on Istanbul Stock Exchange. Journal of Applied Finance\&Banking, Vol.3, No.3, pp. 107-116.

Zeleny, M. (1974). Linear multiobjective programming: Spring 